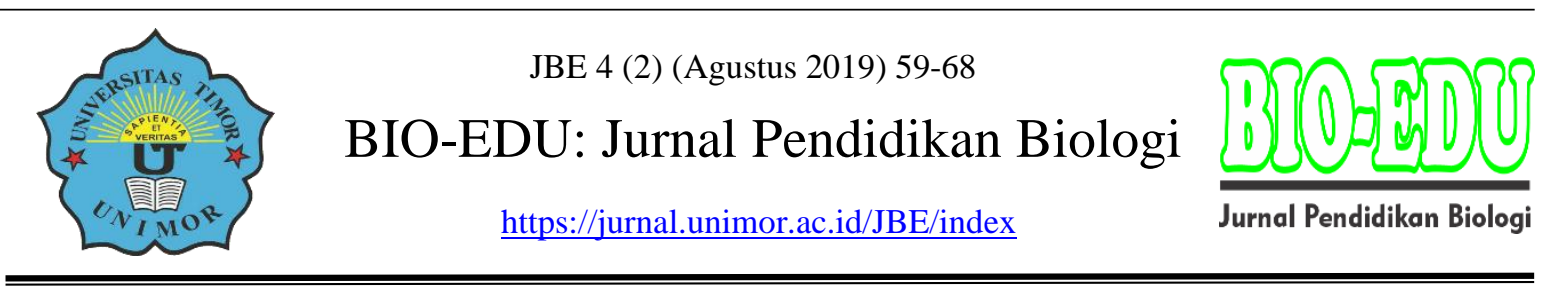

\title{
Pengaruh Pemberian Pakan Alami dan Buatan terhadap Pertumbuhan dan Kelangsungan Hidup Benih Ikan Lele Dumbo (Clarias gariepinus Burchell.) di Balai Benih Sentral Noekele Kabupaten Kupang
}

\author{
Apriani P. Rihi \\ Program Studi Pendidikan Biologi, Universitas Timor \\ Email: aprianapaulina.rihi97@gmail.com
}

DOI: https://doi.org/10.32938/jbe.v4i2.387

\begin{abstract}
Abstrak
Penelitian tentang pengaruh pemberian pakan alami dan buatan terhadap pertumbuhan dan kelangsungan hidup ikan lele dumbo di Balai Benih Sentral Noekele Kabupaten Kupang Provinsi Nusa Tenggara Timur. Balai tersebut hanya menggunakan pakan buatan sebagai pakan ikan sedangkan pakan alami belum pernah digunakan, oleh karena itu peneliti termotivasi untuk menggunakan pakan alami kemudian peneliti ingin melihat bagaimana pengaruh dari pakan alami tersebut.Tujuan dari penelitian ini adalah untuk mengetahui pengaruh pemberian pakan alami dan buatan terhadap pertumbuhan dan kelangsungan hidup ikan lele dumbo (Clarias gariepinus Burchell ) di Balai Benih Sentral Noekele Kabupaten Kupang, mengetahui implementasi hasil penelitian terhadap proses pembelajaran biologi disekolah. Metode yang digunakan dalam penelitian ini adalah penelitian eksperimen dengan menggunakan rancangan percobaan yaitu Rancangan Acak Lengkap (RAL) dengan 3 perlakuan, masing-masing perlakuan diulang sebanyak 3 kali yakni P0 (Kontrol), P1 (Pelet), dan P2 (Cacing sutera). Teknik analisa data yang digunakan dalam penelitian ini adalah penelitian ini dianalisis dengan menggunakan analisis sidik ragam (Anova) sesuai dengan Rancangan Acak Lengkap (RAL). Rata-rata perlakuan selanjutnya diuji dengan menggunakan Duncan Multiple Range Test (DMRT) dengan tingkat signifikan 5\%. Hasil penelitian menunjukan bahwa perlakuan pakan buatan (pelet) dan pakan alami (cacing sutera) menunjukkan beda nyata antar perlakuan terhadap pertumbuhan dan kelangsungan hidup benih ikan lele Dumbo (Clarias gariepinus Burchell.). Hasil pertumbuhan panjang mutlak tertinggi terdapat pada perlakuan P2 Pakan alami cacing sutera sebesar 3,10 cm dan berat mutlak 2,68 gram kelangsungan hidup benih ikan lele dumbo ( Clarias gariepinus Burchell.) tertinggi terdapat pada pakan alami dan buatan yaitu sebesar 100\%.
\end{abstract}

Kata kunci : pakan alami, pakan buatan, clarias gariepinus burchell, pertumbuhan, tingkat kelangsungan hidup Abstract
Research on the effect of natural and artificial feed on the growth and survival of African catfish at the Noekele
Central Seed Center in Kupang Regency, East Nusa Tenggara Province. The center only uses artificial food as
fish food while natural food has never been used, therefore researchers are motivated to use natural food then
researchers want to see how the influence of natural food is. The purpose of this study is to determine the effect
of natural and artificial feeding on the growth and survival of African catfish (Clarias gariepinus Burchell) at
the Noekele Central Seed Center in Kupang Regency, knowing the implementation of research results on the
learning process of biology at school. The method used in this study is an experimental study using an
experimental design that is Completely Randomized Design (CRD) with 3 treatments, each treatment was
repeated 3 times namely P0 (Control), P1 (Pellets), and P2 (Silkworms). The data analysis technique used in 
this study was that this study was analyzed using analysis of variance (Anova) in accordance with the Completely Randomized Design (CRD). The average subsequent treatment was tested using the Duncan Multiple Range Test (DMRT) with a significant level of 5\%. The results showed that the treatment of artificial feed (pellets) and natural feed (silk worms) showed significant differences between the treatments for growth and survival of Dumbo catfish (Clarias gariepinus Burchell.). The highest absolute length growth results were found in the $\mathrm{P} 2$ treatment of natural silk worm feed of $3.10 \mathrm{~cm}$ and the absolute weight of 2.68 grams of survival of African catfish (Clarias gariepinus Burchell.) Highest seeds in natural and artificial food which was 100\%.

Keywords: natural feed, artificial feed, clarias gariepinus burchell, growth, survival rate

\section{PENDAHULUAN}

Indonesia sebagai negara maritim memiliki potensial terbesar di bidang produk perikanan. Salah satu produk perikanan di Indonesia ialah budidaya ikan air laut, air payau, maupun air tawar. Budidaya ikan air tawar menyumbang hingga 1,1 juta ton dan sisanya tambak payau dan laut (Kusmini, et al. 2016). Proses pembudidayaan ikan dibutuhkan adanya kebutuhan pakan pada usaha pembenihan ikan. Pakan yang memenuhi kebutuhan gizi ikan dapat meningkatkan pertumbuhan benih ikan hingga menjadi ukuran siap jual (Madinawati, et al. 2011).

Pertumbuhan dan kelangsungan hidup benih ikan ditentukan oleh kualitas induk, kualitas telur, kualitas air serta perbandingan antara jumlah makanan dan kepadatannya. Untuk mempertahankan kelangsungan hidup dan pertumbuhan ikan, maka diperlukan makanan yang memenuhi kebutuhan nutrisi ikan. Makanan yang dimakan oleh ikan digunakan untuk kelangsungan hidup dan untuk pertumbuhan (Effendi, 2003).

Pakan ikan ada dua macam yaitu pakan alami dan pakan buatan. Pakan alami adalah makanan yang keberadaannya tersedia di alam. Keunggulan dari pakan alami antara lain memiliki kandungan gizi yang cukup tinggi, mudah dicerna, dan gerakan pakan menarik perhatian ikan. Salah satu pakan alami yang paling disukai oleh ikan adalah cacing sutera karena kandungan protein tinggi. Kandungan nutrisi cacing sutera yaitu 54,725\% protein, 13,770\% lemak, 22,250\% karbohidrat (Buwono, 2000).

Pakan buatan adalah makanan yang dibuat dari campuran bahan-bahan alami dan bahan olahan yang selanjutnya dilakukan proses pengolahan serta dibuat dalam bentuk tertentu sehingga tercipta daya tarik (merangsang) ikan untuk memakannya dengan mudah dan lahap. Pakan tepung pelet mengandung 40\% protein, 5\% lemak, 30\% karbohidrat.

Penelitian yang dilakukan (Madinawati et al. 2011), tentang pemberian pakan yang berbeda terhadap pertumbuhan dan kelangsungan hidup ikan lele dumbo (Clarias gariepinus Burchell.) menunjukkan bahwa pemberian pakan alami cacing sutera lebih tinggi dibandingkan dengan pakan buatan pelet dimana menghasilkan pertumbuhan bobot rata-rata pada cacing sutera yaitu $3,26 \mathrm{~g}$ dan pada pelet yaitu $0,78 \mathrm{~g}$.

Berdasarkan hasil observasi yang dilakukan di Balai Benih Sentral Noekele Kabupaten Kupang Provinsi Nusa Tenggara Timur di ketahui bahwa di balai tersebut hanya menggunakan pakan buatan sebagai pakan ikan sedangkan pakan alami belum pernah digunakan, oleh karena itu peneliti termotivasi untuk menggunakan pakan alami.

Berdasarkan uraian latar belakang diatas maka penelitian tentang "Pengaruh Pemberian Pakan Alami dan Buatan Terhadap Pertumbuhan dan Kelangsungan Hidup Ikan Lele Dumbo (Clarias gariepinus Burchell.) di Balai Benih Sentral Noekele Kabupaten Kupang perlu dilakukan. 
Tujuan dari penelitian ini adalah untuk mengetahui pengaruh pemberian pakan alami dan buatan terhadap pertumbuhan dan kelangsungan hidup ikan lele dumbo (Clarias gariepinus Burchell ) di Balai Benih Sentral Noekele Kabupaten Kupang, mengetahui implementasi hasil penelitian terhadap proses pembelajaran biologi disekolah.

\section{METODE}

\section{Waktu dan Tempat penelitian}

Penelitian ini telah dilaksanakan selama 30 hari pada bulan Februari sampai April 2019. Penelitian ini telah dilaksanakan di Laboratorium Balai Benih Ikan Air Tawar Sentral Noekele, Dinas Kelautan dan Perikanan Provinsi Nusa Tenggara Timur.

\section{Alat dan Bahan}

Alat

Alat-alat yang digunakan dalam penelitian ini adalah: akuarium Sebagai tempat pemeliharaan ikan, pH meter Untuk mengukur kadar asam dan basa media uji, Aerator Untuk menjaga kandungan oksigen dalam media, Termometer batang Untuk mengukur suhu, Timbangan analitik Untuk mengukur berat ikan, Mistar. Untuk mengukur panjang ikan, Serok Untuk menangkap ikan, Selang sifon Untuk membuang sisa metabolisme, Alat tulis Untuk mencatat data hasil penelitian, Camera untuk dokumentasi.

\section{Bahan}

Bahan yang digunakan dalam penelitian ini adalah: benih ikan lele dumbo, Pakan alami berupa cacing sutera (Tubifex $s p$ ) dan pakan buatan (pelet), Air sumur.

\section{Rancangan Penelitian}

Penelitian ini merupakan penelitian eksperimen dengan menggunakan rancangan percobaan yaitu Rancangan Acak Lengkap (RAL) dengan 3 perlakuan, masing-masing perlakuan diulang sebanyak 3 kali, yang menjadi perlakuan dalam penelitian ini adalah:

1. Perlakuan P0: Kontrol

2. Perlakuan P1: Pelet

3. Perlakuan P2: Cacing sutera

Prosedur kerja dalam penelitian ini adalah:

1. Persiapan Wadah

2. Persiapan Ikan Uji

3. Persiapan Pakan

4. Pengelolaan air

\section{Populasi dan Sampel}

Populasi dalam penelitian ini adalah semua benih ikan lele dumbo (Clarias gariepinus Burchell.) yang terdapat pada Balai Pembenihan Ikan Air Tawar sedangkan sampel dalam penelitian ini adalah 45 ekor benih ikan lele dumbo sebagai subjek penelitian.

\section{Metode Pengumpulan Data}

Metode yang akan digunakan dalam penelitian ini yaitu metode eksperimen. 
1. Data pertumbuhan ikan lele dumbo

Mengukur panjang panjang ikan menggunakan mistal, menimbang berat ikan menggunakan timbangan analitik setiap seminggu sekali selama satu bulan.

2. Data suhu dan $\mathrm{Ph}$

Mengukur suhu menggunakan termometer batang dan mengukur $\mathrm{pH}$ menggunakan $\mathrm{pH}$ meter setiap seminggu sekali selama satu bulan.

\section{Parameter yang diukur}

1. Pertumbuhan Panjang Mutlak

Pertumbuhan Panjang Mutlak (L) dihitung dengan rumus Arifin dan Rupawan (1997)

diacu oleh Wijayanti (2010):

Keterangan:

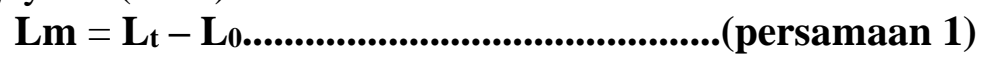
L : Pertumbuhan panjang $(\mathrm{cm})$
Lt $\quad$ : Panjang ikan pada waktu akhir $(\mathrm{cm})$
L0 : Panjang ikan pada waktu awal $(\mathrm{cm})$

2. Laju Pertumbuhan Berat Mutlak

Pertumbuhan bobot mutlak (W) dihitung menggunakan rumus Arifin dan Rupawan (1997) diacu oleh Wijayanti (2010):

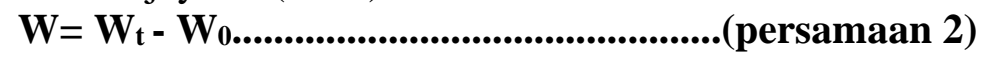

Keterangan:

$\begin{array}{ll}\text { W } & \text { : Pertumbuhan bobot }(\mathrm{g}) \\ \text { W0 } & \text { : Berat ikan pada awal penelitian }(\mathrm{g}) \\ \text { Wt } & \text { : Berat ikan pada akhir penelitian }(\mathrm{g})\end{array}$

3. Tingkat Kelangsungan Hidup

Derajat kelangsungan hidup merupakan presentase dari jumlah ikan yang hidup dan jumlah ikan yang ditebar selama pemeliharaan, dihitung menggunakan rumus Effendie (2002) diacu oleh Amalia dkk (2013) sebagai berikut:

\section{$\mathrm{SR}=\underline{\mathbf{N}_{\mathrm{t}}} / \mathrm{N}_{\mathrm{0}} \mathrm{x} 100 \%$...........................................(persamaan 3$)$}

Keterangan:

SR : kelangsungan hidup benih (\%)

$\mathrm{Nt} \quad$ : Jumlah ikan yang ditebar pada akhir penelitian (ekor)

No : Jumlah ikan yang ditebar pada awal penelitian (ekor)

\section{Teknik Analisa Data}

Data yang diperoleh dalam penelitian ini dianalisis dengan menggunakan analisis sidik ragam (Anova) sesuai dengan Rancangan Acak Lengkap (RAL). Rata-rata perlakuan selanjutnya diuji dengan menggunakan Duncan's Multiple Ranges Test (DMRT) dengan tingkat signifikan 5\% untuk mengetahui letak perbedaan pengaruh antar perlakuan. 


\section{HASIL DAN PEMBAHASAN}

\section{Pengaruh Pemberian Pakan Alami dan Buatan Terhadap Pertumbuhan Ikan Lele Dumbo}

Pertumbuhan adalah pertambahan ukuran, volume seiring dengan berjalannya waktu. Pertumbuhan dapat digunakan sebagai salah satu indikator untuk melihat kesehatan suatu individu atau populasi. Pertumbuhan mutlak terdiri dari dua yaitu pertumbuhan panjang mutlak dan pertumbuhan berat mutlak.

1. Pertumbuhan panjang mutlak

Pertumbuhan panjang mutlak merupakan salah satu kriteria dalam mengetahui laju pertumbuhan panjang mutlak. Berdasarkan hasil penelitian, pertumbuhan panjang mutlak benih ikan lele dumbo selama pemeliharaan 1 bulan. Nilai pertumbuhan panjang mutlak dapat dilihat pada gambar 1 .

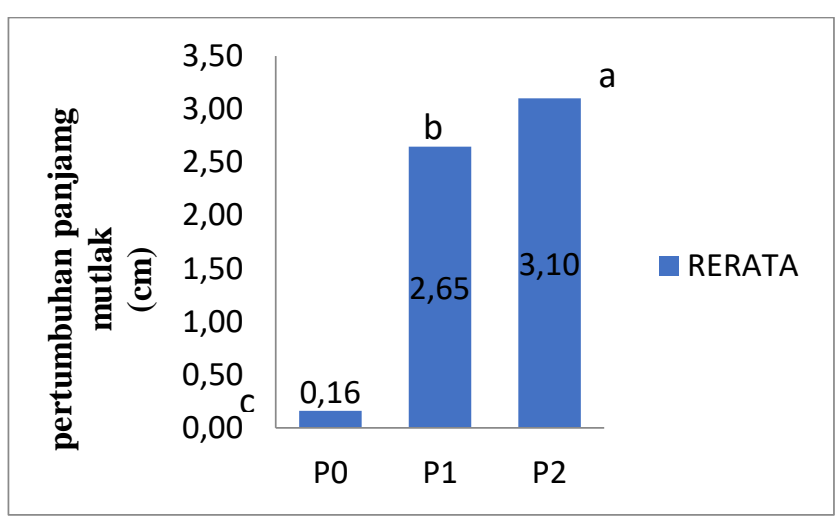

Gambar 1. Pertumbuhan panjang mutlak (cm)

Keterangan: Angka yang diikuti superscript yang sama menunjukan tidak berbeda nyata $(\mathrm{P}>0,05)$ pada $\alpha 0,05$

Hasil sidik ragam (anova) menunjukkan bahwa perlakuan pakan buatan (pelet) dan pakan alami (cacing sutera) menunjukan beda nyata antar perlakuan terhadap parameter pengamatan pertumbuhan panjang mutlak.

Pada gambar 1 terlihat bahwa rata-rata pertumbuhan panjang mutlak ikan lele yang diberi perlakuan pakan alami (cacing sutera) menghasilkan pertumbuhan panjang mutlak tertinggi $(3,10 \mathrm{~cm})$ dibandingkan perlakuan pakan buatan (pelet) $(2,65 \mathrm{~cm})$ dan tanpa perlakuan (control) $(0,16 \mathrm{~cm})$.

\section{Pertumbuhan Berat Mutlak}

Pertumbuhan berat mutlak merupakan salah satu kriteria dalam mengetahui laju pertumbuhan berat mutlak. Nilai pertumbuhan berat mutlak dalam penelitian ini dapat dilihat pada gambar 2 . 


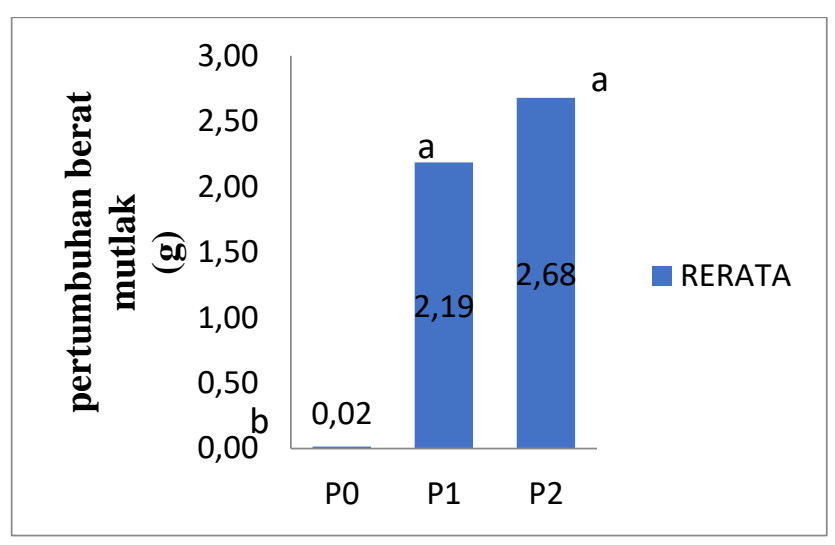

Gambar 2. Pertumbuhan berat mutlak (g)

Keterangan: Angka yang diikuti superscript yang sama menunjukan tidak berbeda nyata $(\mathrm{P}>0,05)$ pada $\alpha 0,05$

Hasil sidik ragam (anova) menunjukkan bahwa perlakuan pakan buatan (pelet) dan pakan alami (cacing sutera) menunjukan beda nyata antar perlakuan terhadap parameter pengamatan pertumbuhan berat mutlak. Pada gambar 2 terlihat bahwa rata-rata pertumbuhan berat mutlak ikan lele yang diberi perlakuan pakan alami (cacing sutera) menghasilkan pertumbuhan berat mutlak tertinggi $(2,68 \mathrm{~g})$ dibandingkan perlakuan pakan buatan (pelet) $(2,19 \mathrm{~g})$ dan tanpa perlakuan (control) $(0,02 \mathrm{~g})$.

Berdasarkan hasil penelitian yang telah saya lakukan, pertumbuhan panjang mutlak dan berat mutlak ikan lele dumbo tertinggi terdapat pakan perlakuan pakan alami (P2) sebesar 3,10 cm dan 2,68 gram pada perlakuan ini frekuensi pemberian pakan sebanyak 3 kali sehari dengan menggunakan pakan alami cacing sutera. Cacing sutera yang diberikan pada ikan lele dumbo mengandung 54,725\% protein, 13,770\% lemak, 22,250\% karbohidrat (Buwono, 2000). Protein ini mampu menjadikan ikan lele dumbo cepat tumbuh, selain itu (Rostika, 1997) juga menyatakan bahwa ikan membutuhkan protein yang tinggi untuk pertumbuhannya dan melalui protein yang tinggi ikan bisa cepat tumbuh dan berkembang.

Peningkatan panjang dan berat ikan lele dumbo disebabkan oleh jumlah nutrisi pakan yang mencukupi. Pada perlakuan P2 jumlah nutrisi tersebut baik itu lemak protein dan karbohidrat terjadi keseimbangan nutrisi yang dibutuhkan untuk pertumbuhan benih ikan lele dumbo. Sesuai dengan (Buwono, 2000) hal itu dikarenakan karbohidrat dan lemak dapat mencukupi kebutuhan kalori tubuh, maka protein hanya sedikit dioksidasi untuk menambah kalori tetapi digunakan untuk zat pembangun pertumbuhan benih ikan.

Rata-rata pertumbuhan panjang dan berat yang kedua terdapat pada pada perlakuan P1 sebesar 2,65 cm dan 2,19 gram pada perlakuan ini frekuensi pemberian pakan sebanyak 3 kali sehari dengan menggunakan pakan buatan pelet. Pelet yang diberikan pada ikan lele dumbo mengandung gizi yang cukup tinggi, sehingga dengan pemberian pakan yang sesuai dengan kebutuhan ikan, selain dapat menjamin kehidupan ikan juga dapat mempercepat pertumbuhannya. Selain itu pakan pelet merupakan jenis pelet tenggelam yang mempunyai daya apung yang rendah, ketika pemberian pakan pada ikan lele dumbo pakan tersebut dengan cepat terlarut dalam air. Hal itu menyebabkan banyaknya jumlah pakan yang terbuang. 
Rata-rata pertumbuhan panjang dan berat terendah terdapat pada kontrol (P0) sebesar $0,16 \mathrm{~cm}$ dan 0,02 gram . Berat badan dan panjang ikan lele dumbo (Clarias gariepinus Burchell.) dalam setiap minggu menurun hal ini sebabkan karena pada kontrol ikan lele dumbo tidak diberi pakan sama sekali.

\section{Tingkat Kelangsungan Hidup}

Tingkat kelangsungan hidup merupakan salah satu kriteria dalam mengetahui jumlah benih ikan lele dumbo pada awal penelitian dan akhir penelitian. Nilai tingkat kelangsungan hidup dalam penelitian ini dapat dilihat pada gambar 3 .

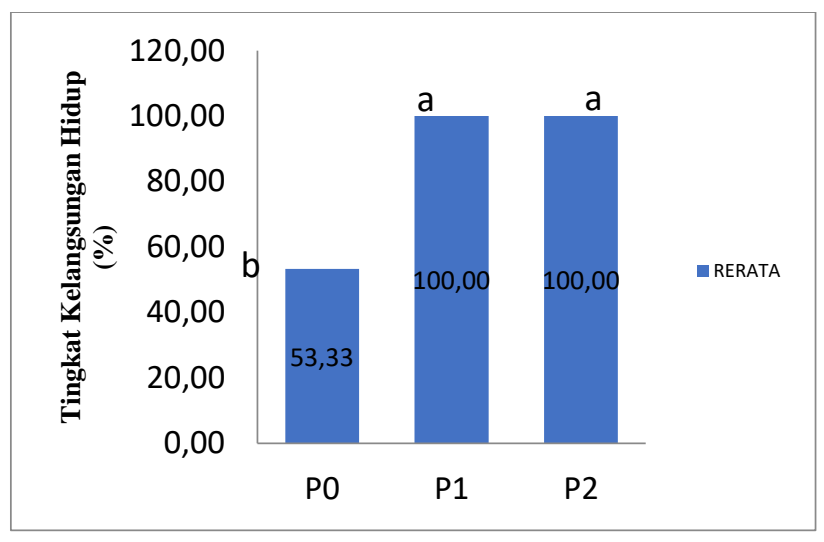

Gambar 3. Tingkat kelangsungan hidup (\%)

Keterangan: Angka yang diikuti superscript yang sama menunjukan tidak berbeda nyata $(\mathrm{P}>0,05)$ pada $\alpha 0,05$

Hasil sidik ragam (anova) menunjukkan bahwa perlakuan pakan buatan (pelet) dan pakan alami (cacing sutera) menunjukan beda nyata antar perlakuan terhadap parameter pengamatan tingkat kelangsungan hidup. Pada gambar 4.3 terlihat bahwa rata-rata tingkat kelangsungan hidup ikan lele yang diberi perlakuan pakan buatan (pelet), pakan alami (cacing sutera) menghasilkan tingkat kelangsungan hidup tertinggi $(100,00 \%)$ dibandingkan tanpa perlakuan (control) $(53,33 \%)$.

Tingkat kelangsungan hidup ikan lele dumbo selama masa pemeliharaan berkisar antara 53,3\% - 100\%. Selama pemeliharaan terjadi kematian beberapa ekor ikan pada kontrol , hal ini lebih banyak terjadi pada hari ke 14 hingga hari ke 15 pemeliharaan. Diduga karena stres akibat belum dapat beradaptasi dengan wadah pemeliharaan yang baru yaitu wadah akuarium. Kematian juga disebabkan oleh ukuran dan umur ikan yang masih rentan untuk dapat bertahan hidup dengan baik, pengaruh respon dari luar misalnya saat penyiponan dan penanganan saat menimbang.

\section{Parameter pendukung}

Pemeliharaan benih ikan lele dumbo tentang pertumbuhan panjang dan berat akan dipengaruhi oleh kualitas air. Parameter kualitas air yang diamati mencakup suhu, dan $\mathrm{pH}$. Berikut data parameter kualitas air yang diamati selama masa pemeliharaan 1 bulan dapat dilihat pada tabel 1 . 
Tabel 1. Parameter Kualitas air selama pengukuran

\begin{tabular}{|c|c|c|}
\hline \multirow{2}{*}{$\begin{array}{c}\text { Waktu } \\
\text { pengamatan }\end{array}$} & \multicolumn{2}{|c|}{ Parameter yang diukur } \\
\cline { 2 - 3 } & Suhu & $\mathrm{Ph}$ \\
\hline 1. & $26-28^{\circ} \mathrm{C}$ & $7,6-8,0$ \\
\hline 2. & $25-26^{\circ} \mathrm{C}$ & $7,8-8,0$ \\
\hline 3. & $25-27^{\circ} \mathrm{C}$ & $7,9-8,0$ \\
\hline 4. & $25-27^{\circ} \mathrm{C}$ & $7,8-8,0$ \\
\hline
\end{tabular}

Air berperan sangat penting sebagai media hidup bagi ikan, maka dalam budidaya perairan, kualitas air atau media hidup bagi ikan mutlak diperhatikan demi menjaga kehidupan yang sesuai bagi ikan budidaya. Hasil pengukuran suhu selama penelitian adalah $25-28^{\circ} \mathrm{C}$ telah sesuai dengan suhu yang optimal bagi pertumbuhan benih ikan lele dumbo. Menurut(Khairuman, et al. 2011) menyatakan bahwa suhu yang cocok untuk memelihara lele dumbo adalah $20-30^{\circ} \mathrm{C}$. Suhu yang sesuai akan meningkatkan aktivitas makan ikan, sehingga menjadikan ikan lele dumbo cepat tumbuh

Derajat keasaman $(\mathrm{pH})$ merupakan kemampuan air untuk mengikat atau melepaskan sejumlah ion hidrogen akan menunjukkan apakah larutan tersebut bersifat asam atau basa. Nilai pengukuran $\mathrm{pH}$ selama penelitian adalah berkisar antara 7,8 - 8,0. Sebagaimana dinyatakan oleh (Khairuman, et al. 2008), umumnya ikan lele dumbo dapat hidup diperairan dengan $\mathrm{pH}$ berkisar antara 6,5-8.

\section{Implementasi Penelitian Terhadap Proses Pembelajaran Biologi}

Hasil penelitian tentang pengaruh pemberian pakan alami dan buatan terhadap pertumbuhan dan kelangsungan hidup ikan lele dumbo (Clarias gariepinus Burchell.) di Balai Benih Sentral Noekele Kabupaten Kupang dapat diimplementasikan pada proses pembelajaran biologi tingkat Sekolah menengah Pertama (SMP) kelas 7 pada materi Klasifikasi Makluk Hidup, Sekolah Menengah Atas (SMA) kelas X pada materi Animalia (Dunia Hewan .) dan pada Sekolah Menengah Kejuruan (SMK) pada materi Struktur dan Fungsi Jaringan Hewan. Acuan kurikulum yang digunakan dalam desain pembelajaran terkait dengan penelitian yang telah dilakukan adalah kurikulum 2013.

\section{KESIMPULAN DAN SARAN}

\section{Kesimpulan}

Kesimpulan dari penelitian ini adalah:

1. Terdapat perbedaan pengaruh pemberian pakan alami terhadap pertumbuhan ikan lele dumbo, dimana panjang dan berat pada pakan alami lebih besar dari pada pakan buatan yaitu sebesar 3,10 cm dan 2,68 gram.

2. Terdapat pengaruh pemberian pakan alami dan buatan terhadap Tingkat kelangsungan hidup dari masing-masing perlakuan P1 dan P2 adalah 100\% kecuali pada kontrol (P0) $53,33 \%$.

3. Hasil penelitian dapat diimplementasikan pada proses pembelajaran biologi tingkat Sekolah menengah Pertama (SMP) kelas 7 pada materi Klasifikasi Makluk Hidup, Sekolah Menengah Atas (SMA) kelas X pada materi Animalia (Dunia Hewan) dan pada Sekolah Menengah Kejuruan (SMK) pada materi Struktur dan Fungsi Jaringan Hewan. 


\section{Saran}

Saran dari penelitian ini adalah sebagai berikut:

1. Perlu dilakukan penelitian lanjutan dengan menggunakan metode yang berbeda.

2. Perlu dilakukan penelitian lebih lanjut mengenai kombinasi pakan alami dan buatan terhadap pertumbuhan dan kelangsungan hidup ikan lele dumbo.

\section{DAFTAR RUJUKAN}

Affandi, R. dan U.M. Tang. 2002. Fisiologi Hewan Air. Universitas Riau Press.Riau.

Arief, M., N. Fitriani dan S. Subekti. 2014. Pengaruh Pemberian Probiotik Berbeda Pada Pakan Komersial Terhadap Pertumbuhan dan Efisiensi Pakan Ikan Lele Sangkuriang (Clarias Sp.). Jurnal Ilmiah Perikanan dan Kelautan Vol 6(1) : 49 - 53.

Anggraeni,N.M dan N. Abdulgani.2013.Pengaruh Pemberian Pakan Alami dan Pakan Buatan Terhadap Pertumbuhan Ikan Betutu (Oxyeleotris marmota) Pada Skala Laboratorium. Jurnal Sains dan Seni Pomits Vol 2(1) : 197-201.

Barus, T.A. 2002. Pengantar Limnologi. Univertas Sumatera Utara. Medan.

Buwono, I.D. 2000. Kebutuhan Asam Amino Esensial Dalam Ransum Ikan. Kanisius. Yogyakarta.

Brotoadji.2011. Kiat Sukses Budidaya Ikan Lele. Yogyakarta: PT Citra Aji Parama.

Cahyono, B. 2009. Budidaya lele dan Betutu (ikan langkah bernilai tinggi), Pustaka Mina. Jakarta.

Effendi, I dan Y. Hadiroseyani. 2002. Peningkatan Kelangsungan Hidup Larva Ikan Betutu, Oxyeleotris marmorata (Blkr.) dengan Antibiotik. Jurnal Akuakultur Indonesia Vol 1(1) : $9-13$.

Effendi, H. 2003. Telaah Kualitas Air Bagi Pengelolaan Sumberdaya dan lingkungan Perairan. Penerbit Kanisius. Yogyakarta. Edisi II. 258 hal.

Khairuman \& K. Amri. 2012. Buku Pintar Budidaya 15 Ikan Konsumsi. Agromedia Pustaka, Jakarta.

Madinawati., N. Serdiati \&Yoel. 2011. Pemberian Pakan yang Berbeda Terhadap Pertumbuhan dan Kelangsungan Hidup Ikan Lele Dumbo (Clarias gariepinus). Media Litbang Sulteng IV. Volum 2.

Marmota ) Pada Skala Laboratorium. Jurnal Sains Dan Seni Pomints Vol. 2, No.1.

Muchlisin, Z. A., A. Damhoeri, R. Fauziah, Muhammadar \& M. Musman. 2003. Pengaruh Beberapa Jenis Pakan Alami Terhadap Pertumbuhan dan Kelulushidupan Larva Ikan Lele Dumbo (Clarias gariepinus). Jurnal Biologi Vol 3(2) : 105 - 113.

Mujiman, A. (2000). Makanan Ikan. Jakarta: Penebar Swadaya.

Nizar, S. 2006. Pengaruh Pemberian Probiotik Dengan Dosis Yang Berbeda Pada Pakan Buatan Terhadap Laju Pertumbuhan dan Konversi Pakan Benih Ikan Patin (Pangasius sp.) Skripsi. Semarang:Fakultas Perikanan dan Kelautan UNDIP. 
Santoso, B. 1993. Petunjuk Praktis Budidaya: Ikan Mas. Kanisius, Yogyakarta. 77p.

68|Rihi/JBE 4(2) (Agustus 2019) $59-68$ 